\title{
EFFECTS OF POST-EMERGENCE HERBICIDES ON IN VITRO GROWTH OF FUSARIUM OXYSPORUM ISOLATED FROM RED CLOVER ROOT ROT
}

\author{
R. Ceballos ${ }^{1}$, A. Quiroz ${ }^{2}$, and G. Palma ${ }^{2}$ \\ ${ }^{1}$ Laboratorio de Ecología Química; Instituto de Investigaciones Agropecuarias, CRI-Quilamapu. \\ Av. Vicente Méndez 515, Casilla 426, Chillán Chile. ${ }^{2}$ Departamento de Ciencias Químicas y \\ Recursos Naturales. Universidad de La Frontera. Casilla 54-D. Temuco, Chile. \\ *Corresponding author: rceballos@,inia.cl
}

\begin{abstract}
In Chile, Fusarium root rot reduces red clover (Trifolium pretense L.) pasture yield and persistence. Fusarium oxysporum (Schlect.) is the most prevalent pathogen in diseased red clover plant roots. Agronomic management of red clover includes applying herbicides such as MCPA, 2,4-DB, flumetsulam, bentazon, and haloxyfop-methyl. In addition to weed control, herbicides can modify disease development, generally as a result of the interaction between direct effects on the pathogen and indirect effects via plant-mediated responses. The objective of this study was to evaluate the influence of these herbicides on in vitro growth of $F$. oxysporum at four application rates $0,50,100$, and $200 \%$ at the field-recommended active ingredient rate. Herbicides were amended on Petri dishes containing potato dextrose agar (PDA) and buffer MUB (trishydroxymethyl-aminomethane). Fusarium oxysporum was cultivated at $22^{\circ} \mathrm{C}$ for 25 days and colony area was measured every 5 days. The herbicides MCPA and Flumetsulam had no effect on fungal growth. 2,4-DB showing an inverse dose effect on fungal growth varying between 16 and $35 \%$ at the end of the experimental period. The contact herbicide Bentazon exhibited the strongest inhibitory effect on $F$. oxysporum development by the application of the field recommended rate, with a $54 \%$ decrease with regard to the control at the end of the experiment. Haloxyfop-methyl showed the highest colony stimulation since 15 days after of the application, increasing $29 \%$ the colony area respect to the control at the end of the experiment. These results suggest that applying some herbicides to red clover could affect soil pathogens such as Fusarium oxysporum, increasing or inhibiting its development.
\end{abstract}

Keywords: phytopathogenic fungi, root diseases, mycelial growth.

\section{INTRODUCTION}

Red clover (Trifolium pratense L.) is an important perennial forage legume grown in southern Chile with $100 \quad 000$ ha producing an average annual yield of 7 tons $\mathrm{ha}^{-1}$. Although red clover is considered a perennial species, its yield declines each year and rarely persists more than 2 or 3 years. Root rot, caused by infestations of certain Fusarium species and root borer, Hylastinus obscurus (Marsham) (Coleoptera: Scolytidae), are responsible for its short 
persistence not only locally but worldwide (Steiner and Alderman, 1999). Fusarium root rot is a common disease in red clover pastures in Chile as well as in other areas in the world (Ceballos et al., 2004, 2006; Steiner and Alderman, 1999), in which reduces productivity and persistence (Venuto et al., 1999). Fusarium oxysporum Schldt. is the most commonly studied and economically important Fusarium species (Ceballos et al., 2004; 2006; Venuto et al., 1999).

Chemical weed control is currently a critical part of agricultural management to maximize red clover yield. The majority of postemergence herbicides presently used to protect red clover growth in Chile, and worldwide include MCPA ((4-chloro2-methylphenoxy) acetic acid) and bentazon (3-(1-methylethyl)-1H-2,1,3benzothiadiazin-4(3H)-one-2,2 dioxide). Others, such as 2,4-DB (4-(2,4dichlorophenoxy) butanoic acid), flumetsulam (N-(2,6-difluorophenyl)-5methyl $(1,2,4)$ triazolo $(1,5-a)$ pyrimidine2-sulfonamide), and haloxyfop-methyl (2(4-(3-chloro-5-trifluoromethyl

pyridyloxy) phenoxy) propionic acid) are less used (AFIPA, 2002; Kuds and Streibig, 2003). All these herbicides are described as highly selective. MCPA and 2.4-DB are systemic hormone-like herbicides absorbed by leaves, and also by roots as in the case of MCPA. Bentazon is a contact herbicide which acts directly where it is absorbed, primarily by foliage, but also by roots. Flumetsulam and haloxyfop-methyl are systemic herbicides absorbed by roots and leaves (Tomlin, 2003).

Besides affecting target weeds, herbicides can interact in several ways with plants and soil microorganisms that can influence the plant-pathogen relationship (Duke et al., 2007). Herbicides produce changes in the physiology and development of crop plants, thus increasing disease susceptibility. Herbicides can modify host plant structure and defense mechanisms which may lead to greater susceptibility to infection (Smiley and Wilkins, 1992). These changes include plant exudate modification and associated microorganism stimulation or inhibition (Mussa and Russel, 1977). In this context, herbicides are reported as affecting incidence and severity of plant diseases by interacting with plants, pathogens, or other microorganisms (Heydari and Misaghi, 2003). A number of plant diseases are reported to increase incidence and severity after applying herbicides (Duke et al., 2007; Sanogo et al., 2000). Other diseases have shown either decreases or no significant changes (Dann et al., 1999). No information is available on the consequences of non-target effects of these herbicides on Fusarium oxysporum. As such, the purpose of this research study was to evaluate the primary effects of selected herbicides on Fusarium oxysporum growth under in vitro conditions.

\section{MATERIALS AND METHODS}

\section{Herbicides}

This study was carried out with two independent experiments. Stock herbicide solutions were prepared by mixing commercial formulations in sterile water considering $200 \mathrm{~L}$ as the field application volume. The experiment consisted of the following herbicides: MCPA ((4-chloro-2-methylphenoxy) acetic acid), bentazon (3-(1-methylethyl)$1 \mathrm{H}-2,1,3$-benzothiadiazin-4(3H)- one-2, 2 dioxide), 2,4-DB (4-(2,4dichlorophenoxy) butanoic acid), flumetsulam (N-(2,6-difluorophenyl)-5methyl $(1,2,4) \quad$ triazolo $(1,5-\mathrm{a})$ pyrimidine-2-sulfonamide), and 
haloxyfop-methyl (2-(4-(3-chloro-5trifluoromethyl pyridyloxy) phenoxy) propionic acid). The assay was conducted under laboratory conditions and herbicides were applied at $0 \%$ (Control), 50\% (0.5X), 100\% (1X), and $200 \%$ (2X) which the rate applied by Chilean farmers for red clover (Table 1).

Table 1. Field-recommended active ingredient herbicide rate.

\begin{tabular}{|c|c|c|c|}
\hline Herbicide & Commercial formulation ${ }^{\text {a }}$ & $\begin{array}{c}\text { Rate } \\
\left(\text { g a.i. } \mathbf{h a}^{-1}\right)\end{array}$ & $\begin{array}{c}\text { Rate / Dish } \\
\text { ( } \mu \text { g i.a. })\end{array}$ \\
\hline MCPA & MCPA $750 \mathrm{LS}$ & 750 & 47.7 \\
\hline 2,4-DB & Venceweed $775 \mathrm{CE}$ & 388 & 24.7 \\
\hline Flumetsulam & Preside $80 \mathrm{G}$ & 39 & 2.5 \\
\hline Bentazon & Bentazon CS & 1200 & 76.0 \\
\hline Haloxyfop-methyl & Galant Plus $30 \mathrm{CE}$ & 30 & 1.9 \\
\hline
\end{tabular}

${ }^{a}$ CS: concentrate suspension; CE: concentrate emulsion; LS: liquid suspension; G: granules.

\section{Fusarium isolate}

Fusarium oxysporum isolates were collected in the Carillanca Experimental Station of the Instituto de Investigaciones Agropecuarias, Temuco, Chile and produced from diseased red clover plants with evident vascular wilt symptoms. Symptomatic root rot tissue was cut into 1-cm lengths, washed in distilled water, and soaked in a $1 \% \mathrm{NaOCl}$ solution for 3 min (Akinsanmi et al., 2004). A $1-\mathrm{cm}$ subsection was cut from each sterilized section and placed on Petri dishes containing potato dextrose agar $\left(39 \mathrm{~g} \mathrm{~L}^{-1}\right.$ PDA, Difco) and streptomycin sulphate (100 $\left.\mathrm{mg} \mathrm{L}^{-1}\right)$. Dishes were incubated at $25^{\circ} \mathrm{C}$ for $14 \mathrm{~d}$. Assays of Fusarium isolate pathogenicity $\mathrm{s}$ were performed with Quiñequeli red clover cultivar. The F127 isolate was identified as the most pathogenic, and was transferred to fresh PDA to complete Koch's postulates and continue the experiments (Ceballos et al., 2006). The specific characterization of this strain is F. oxysporum (IMI 390980), and was provided by CABI Bioscience Identification Services, UK Centre (Egham).

\section{Herbicide effects on in vitro mycelial growth}

This study was carried out in optimal nutritional conditions for mycelial growth of F. oxysporum (Sanogo et al., 2000). Potato dextrose agar (PDA, Difco) was amended with buffer MUB (trishydroxymethyl-aminomethane) to avoid $\mathrm{pH}$ modification by herbicide solutions. Commercial formulations of MCPA, haloxyfop-methyl, bentazon, flumetsulam and 2,4-DB were added to the agar dishes at the four rates previously described. A 5-mm diameter agar plug was collected from the edge of the actively growing F127colony (2-weekold culture), placed in the center of the herbicide-amended dishes (90 $\mathrm{mm}$ diameter), and incubated at $22^{\circ} \mathrm{C}$ in complete darkness.

\section{Data analysis}

Since colony growth was irregular, it was recorded by drawing its shape on a plastic film (Figure 1). The F. oxysporum colony area was calculated by scanning each plastic drawing with DIAS software. Growth was regularly recorded every $5 \mathrm{~d}$ 
for $25 \mathrm{~d}$, each treatment was replicated six times, and arranged in a completely randomized design. Area at the end of the experiment was compared by ANOVA, and group separation was performed with the Tukey test $(p \leq 0.05)$ (Conover, 1999). Data were analyzed with StatsDirect statistical software, Version 2.7.2.

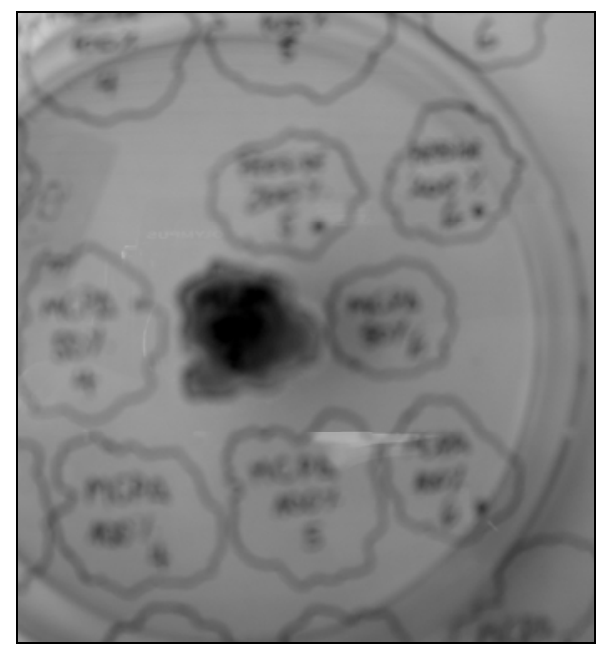

Figure 1. Plastic film to record irregular growth of Fusarium oxysporum colonies.

\section{RESULTS AND DISCUSSION}

The systemic herbicides MCPA and Flumetsulam did not show any statistical differences respect control throughout the experiment (Table 2). Bentazon, a type of contact herbicide, has no effect on fungal growth at the highest rate; though the $F$. oxysporum colony was significantly inhibited at the end of the assay with 54\% at the field recommended rate (Table 2). Fusarium oxysporum growth in media amended with 2,4-DB decreased for all test rates (Table 2), 2,4-DB showed a significant inhibitory effect on fungal growth since 10 days after their application, and at the end of the experiment the detrimental effect was 35 , 28 , and $16 \%$ for $0.5 \mathrm{X}, 1 \mathrm{X}$, and $2 \mathrm{X}$ rates, respectively (Table 2 ).

On the other hand, haloxyfop-methyl had a significant stimulant effect on fungus growth with the $2 \mathrm{X}$ rate, starting this effect at 15 days after their application (Table 2). By the end of the experiment, the colony was stimulated by $29 \%$ at the $2 \mathrm{X}$ rate (Table 2).

Stimulation of Fusarium spp. growth by some herbicides has also been reported (Mussa and Rusell, 1977). In this context, in a greenhouse study with the same herbicide rate, Ceballos et al. (2006) showed that MCPA increased the severity of fusarium root rot in red clover seedlings. Other studies with Fusarium spp. have also shown inhibitory responses (Grossbard, 1976). The variable responses of the herbicide fungi-toxic effect could be a result of the modification of the medium nutrient component with toxic substances from herbicide degradation (Liu et al., 1997).

On the other hand, the effect of an herbicide on disease levels is not always the same as its effect on pathogen in vitro growth studies (Sanogo et al., 2000) because direct contact between pathogen and herbicide would not be as likely to occur under complex natural environmental conditions. Herbicide stress weakens and predisposes plants to a rapid fungal colonization (Sanogo et al., 2000; Ceballos et al., 2006) and could explain the significant increase in disease severity and pathogen isolation frequency after applying some herbicides (Sanogo et al., 2000).

Herbicide activity can be extended beyond its target organisms and its effects on various plant pathogens under laboratory conditions have been reported (Mussa and Russel, 1977; Heydari and Misaghi, 2003; Duke et al., 2007; Ceballos et al., 2009). In addition to weed 
Table 2. Fusarium oxysporum growth $\left(\mathrm{mm}^{2}\right)$ in media amended with four rates of five herbicides.

\begin{tabular}{|c|c|c|c|c|c|c|c|c|}
\hline \multirow{2}{*}{$\begin{array}{l}\text { Days after } \\
\text { application }\end{array}$} & \multicolumn{8}{|c|}{ Proportion of the field-recommended rate } \\
\hline & \multicolumn{2}{|c|}{$\mathbf{0}$} & \multicolumn{2}{|c|}{0.5} & \multicolumn{2}{|l|}{1} & \multicolumn{2}{|l|}{2} \\
\hline \multicolumn{9}{|l|}{ МСРА } \\
\hline 5 & 3.7 & ed & 2.5 & $\mathbf{e}$ & 3.2 & ed & 3.3 & ed \\
\hline 10 & 13.1 & cd & 8.4 & ed & 11.4 & cde & 10.3 & cde \\
\hline 15 & 20.5 & bc & 15.9 & bc & 20.7 & bc & 20.6 & bc \\
\hline 20 & 27.4 & $\mathbf{a b}$ & 20.7 & bc & 26.8 & $\mathbf{a b}$ & 27.4 & $\mathbf{a b}$ \\
\hline 25 & 31.8 & $\mathbf{a}$ & 25.2 & $\mathbf{a b}$ & 32.1 & $\mathbf{a}$ & 34.8 & $\mathbf{a}$ \\
\hline \multicolumn{9}{|l|}{$2,4-D B$} \\
\hline 5 & 3.7 & hi & 2.4 & i & 3.0 & hi & 2.5 & $\mathbf{i}$ \\
\hline 10 & 13.1 & g & 6.3 & hi & 7.1 & $\mathbf{h}$ & 6.0 & hi \\
\hline 15 & 20.5 & def & 12.1 & g & 13.5 & g & 13.4 & g \\
\hline 20 & 27.4 & $\mathbf{b}$ & 16.3 & fg & 18.2 & ef & 20.3 & def \\
\hline 25 & 31.8 & $\mathbf{a}$ & 20.8 & de & 23.0 & cd & 26.8 & bc \\
\hline \multicolumn{9}{|c|}{ Flumetsulam } \\
\hline 5 & 3.7 & $\mathbf{h}$ & 2.9 & $\mathbf{h}$ & 3.0 & h & 3.1 & $\mathbf{h}$ \\
\hline 10 & 13.1 & g & 9.8 & g & 9.8 & g & 12.0 & g \\
\hline 15 & 20.5 & ef & 17.7 & g & 20.1 & ef & 21.2 & ef \\
\hline 20 & 27.4 & bcd & 21.7 & ef & 24.2 & de & 26.4 & cd \\
\hline 25 & 31.8 & $\mathbf{a b}$ & 28.0 & bcd & 30.8 & abc & 32.6 & $\mathbf{a}$ \\
\hline \multicolumn{9}{|c|}{ Haloxyfop-methyl } \\
\hline 5 & 3.7 & $\mathbf{i}$ & 3.1 & i & 3.7 & i & 4.7 & hi \\
\hline 10 & 13.1 & fg & 12.3 & hg & 18.6 & efg & 16.9 & fg \\
\hline 15 & 20.5 & def & 21.0 & def & 26.2 & c & 29.2 & bc \\
\hline 20 & 27.4 & cd & 25.3 & cde & 30.1 & bc & 35.8 & $\mathbf{a b}$ \\
\hline 25 & 31.8 & bc & 28.4 & c & 38.5 & ab & 41.1 & $\mathbf{a}$ \\
\hline \multicolumn{9}{|l|}{ Bentazon } \\
\hline 5 & 3.7 & d & 2.7 & d & 3.1 & d & 3.7 & d \\
\hline 10 & 13.1 & cd & 9.0 & cd & 8.7 & cd & 11.8 & cd \\
\hline 15 & 20.5 & abc & 15.6 & bcd & 10.7 & cd & 21.0 & abc \\
\hline 20 & 27.4 & $\mathbf{a b}$ & 19.1 & abc & 12.8 & cd & 27.7 & ab \\
\hline 25 & 31.8 & $\mathbf{a}$ & 22.5 & abc & 14.6 & bcd & 32.8 & $\mathbf{a}$ \\
\hline
\end{tabular}

Means sharing a letter in common, for each herbicide, do not differ significantly according to Tukey test $(p \leq 0.05)$.

control, herbicides can modify disease development, generally as a result of the interaction between direct effects on the pathogen and indirect effects via plantmediated responses (Duke et al., 2007; Sanogo et al., 2000). The range of 
herbicide concentrations was selected to represent actual production fields at the recommended rate $(1 \mathrm{X})$ and an accidental overlap of spray coverage (2X). The pathogen could adsorb herbicide directly from the spray solution or from plant residues that could be translocated from the roots or foliage (Sanogo et al., 2000). This is a complex topic because of the intricate interactions among herbicide dose, formulation, tillage system, environmental conditions, pathogen, and the plant involved. Furthermore, the timing of infection with the pathogen $v s$. herbicide treatment can have a profound influence on the interaction. Although the literature often appears to be conflicting, apparent divergences may be due to differences in one or more of the factors involved. However, it is necessary that these results be validated with field experiments.

\section{CONCLUSIONS}

Overall our results suggest that various herbicides used to protect red clover against weeds could affect some root pathogen microorganisms, such as Fusarium oxysporum. The inhibition or stimulation of the fungal colony develop could be explain by mean of the products that occur in the modification of the medium nutrient and herbicide degradation by the fungus itself. It is clear that further studies are necessary since Fusarium oxysporum is the greatest cause of disease in red clover in Chile. Moreover, this research study was conducted under laboratory conditions and does not represent what could occur under field conditions where environmental factors influence the interactions between herbicide effects on Fusarium oxysporum and red clover.

\section{ACKNOWLEGEMENTS}

Financial support for this research study was provided by FONDECYT 1020297, DI-10-1002 and CONICYT PBCYT PSD05 Projects.

\section{REFERENCES}

AFIPA. 2002. Manual fitosanitario Asociación de distribuidores de plaguicidas, Santiago. Chile. $677 \mathrm{pp}$.

Akinsanmi, O.A., Mitter, V., Simpfendorfer, S., Backhouse, D., Chakraborty, S. 2004. Identity and pathogenicity of Fusarium spp. isolated from wheat fields in Queensland and northern New South Wales. Aus. J. Agr. Res. 55, 97-107.

Ceballos, R., Palma, G., Brevis, H., Ortega, F., Quiroz, A. 2004. The effect of five postemergence herbicides on red clover shoot and root growth in greenhouse studies. Phytoprotection 85, 153-160.

Ceballos, R., Palma, G., Perich, F., Pardo, F., Quiroz, A. 2006. Influence of MCPA on Fusarium oxysporum root rot and red clover growth under controlled greenhouse conditions. Phytoprotection 87, 9-15.

Ceballos, R., Cofré, X., Quiroz, A., Espinoza, N., Palma, G. 2009. Bentazon-MCPA effect on Fusarium oxysporum root rot on Trifolium pratense in greenhouse conditions. J. Soil. Sci. Plant Nutr. 9, 142-154.

Conover, W.J. 1999. Practical nonparametric statistics. 3rd ed. Wiley, New York; Chichester. $584 \mathrm{p}$.

Dann, E.K., Diers, B.W., Hammerschmidt, R. 1999. Suppression of Sclerotinia stem rot of soybean by lactofen herbicide treatment. Phytopathology 89, 598-602.

Duke, S., Wedge, D., Cerdeira, A. and, Matallo, M. 2007. Herbicide effects on plant disease. Outlooks Pest Manage 18, 3640.

Heydari, A., Misaghi, I.J. 2003. The role of rhizosphere bacteria in herbicide-mediated 
increase in Rhizoctonia solani-induced cotton seedling damping-off. Plant Soil 257, 391-396.

Kuds, P., Streibig, J. 2003. Herbicide a two edged sword. Weed Res. 43, 90-102.

Mussa, A., Russell, P. 1977. The influence of pesticides and herbicides on the growth and virulence of Fusarium solani f.sp. phaseoli. J. Agr. Sci. 88, 705-709.

Sanogo, S., Yang, X.B., Scherm, H. 2000 Effects of herbicides on Fusarium solani f. sp glycines and development of sudden death syndrome in glyphosate-tolerant soybean. Phytopathology 90, 57-66.
Smiley, R.W., Wilkins, D.E. 1992. Impact of sulfonylurea herbicides on Rhizoctonia root rot, growth and yield of winter wheat. Plant Dis. 76, 399-404.

Steiner, J.J., Alderman, S.C. 1999. Red clover seed production: V. Root health and crop productivity. Crop Sci. 39, 1407-1415.

Tomlin, C. 2003. The Pesticide manual: A world compendium of pesticides. 13th ed. British crop Protection Council, Farnham, UK. 1344 pp.

Venuto, B.C., Smith, R.R., Grau, C.R. 1999

Selection for resistance to Fusarium wilts in red clover. Can. J. Plant Sci. 79, 351-356. 